\section{HSE}

Historia Social y de la Educación

Social and Education History
Hipatia Press

www.hipatiapress.com

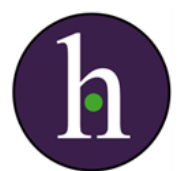

Instructions for authors, subscriptions and further details:

http://hse.hipatiapress.com

\title{
Education across Europe: a visual conversation
}

Estefanía Fernández Antón ${ }^{1}$

1) Universidad de Barcelona (España)

Date of publication: February $23^{\text {rd }}, 2016$

Edition period: Edition period: February 2016-June 2016

To cite this article: Fernández Antón, E. (2014). Education across Europe: a visual conversation [Review of the book]. Social and Education History 5(1), 105-107 doi:10.17583/hse.2016.1870

To link this article: http://dx.doi.org/10.17583/hse.2016.1870

\section{PLEASE SCROLL DOWN FOR ARTICLE}

The terms and conditions of use are related to the Open Journal System and to Creative Commons Attribution License (CC-BY). 


\section{Reviews (I)}

Burke, C., Grosvenor, I., Haenggeli-Jenni, B., Ribeiro de Castro, H., Tabacchi, E., Thyssen, G., \& Verstraete, P. (Eds) (2014). Education across Europe: a visual conversation. Lisboa: EERA, Network 17.

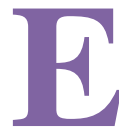

1 libro Education across Europe. A visual Conversation está constituido por el trabajo de veinticuatro investigadores que conforman la European Educational Research Association (EERA). La historia de la educación es la disciplina en la que se sitúa el escrito; por lo tanto, se parcela un pedazo de realidad del pasado y se presenta sin olvidar lo momentos sociales y políticos del momento.

El libro está dividido en veinticuatros capítulos; cada uno de ellos se centra en un país europeo para desvelar algunas de sus tradiciones y métodos pedagógicos. Los lugares de Europa seleccionados son Armenia, Austria, Bélgica, Dinamarca, Estonia, Finlandia, Francia, Alemania, Grecia, Hungría, Italia, Letonia, Luxemburgo, Países Bajos, Noruega, Polonia, Portugal, Serbia, Eslovenia, España, Suecia, Suiza, Turquía y Reino Unido.

Las secciones se conforman de una explicación breve y sencilla del pasado de la educación; no interesa tanto un análisis completo -de principio a fin-, lo que importa sobre todo son momentos fáciles de entender y abordar que, en muchos casos, fueron clave para la renovación de la pedagogía.

Las reducidas historias están acompañadas de retratos escolares realizados entre principios del siglo XIX y finales del siglo XX. Algunas imágenes ya forman parte de la memoria colectiva, al representar sistemas escolares 2016 Hipatia Press

ISSN: 2014-3567

DOI: $10.17583 / \mathrm{hse} .2016 .1870$

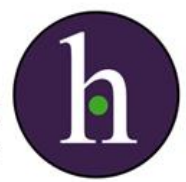




\section{Fernández - Education across Europe [Review]}

vinculados al trabajo físico, al procesamiento de materias primas y a la estratificación social. Otros ejemplos que nos recuerdan al pasado son las clases atestadas de alumnos, la escolarización de niñas por un lado y la escolarización de niños por otro, el profesor que solo explica, el alumno que solo memoriza, etc.

Sin embargo, otras imágenes y relatos nos pillan por sorpresa al no ceñirse a lo que suele entenderse como educación en tiempos remotos. Hablamos de alumnado reunido en grupo para aprender, y no solo de eso, sino de grupos en los que los alumnos están cerca los unos de los otros, y el profesorado forma parte de la agrupación. Esta reforma pedagógica recibe el nombre de Landschulerneuerung y tiene lugar en Austria después de la segunda guerra mundial. La reforma supone el despertar de la pedagogía basada en la cohesión social y en la calidez del ambiente; estos dos factores se entendían como bases cruciales para dar los primeros pasos hacia la escuela ideal.

Otro documento escrito y gráfico, que desconcierta, alberga el Seminario Didáctico-Metodológico de la Universidad de Tartu; desde el cual se formaban a los profesores de Educación Secundaria de Estonia. El método implicó una nueva forma de entender la capacitación de los docentes, al estar unido con el pensamiento pedagógico progresista o escuela nueva. Estas pedagogías, de carácter crítico y de finales del siglo XIX, apuntaron hacia la transformación del autoritarismo del profesorado y pasividad del alumnado. Respaldando, entonces, una relación democrática y colaborativa entre enseñante y aprendiz. También hay que indicar que es en la pedagogía crítica donde se apuesta por la educación como palanca de cambio de la sociedad.

En el caso español se destacan dos experiencias consideradas revolucionarias y críticas, la Institución Libre de Enseñanza y el proyecto Comunidades de Aprendizaje. En relación a las Comunidades de Aprendizaje se identifica su impacto internacional, ya que después de su surgimiento en España a finales de los años 70, este proyecto basado en las aportaciones de la comunidad científica internacional se ha transferido exitosamente a diversos países como Brasil, México o Inglaterra, entre otros. 
A largo del libro hay más ejemplos que concuerdan con la idea que tenemos de educación del pasado y otros que rompen con ella. Sin embargo, hemos seleccionado los casos del escrito que mejor representan lo uno y lo otro y, sobre todo, los que representan la revolución de la pedagogía.

El libro no solo está dispuesto a acreditar el pasado como transformador de la pedagogía, sino que también recomienda aprender de él y llevar el conocimiento al aula. Un ejemplo de esto lo encontramos en el capítulo dedicado a Bélgica, en el cual se cita el documental Herman Slosse/Blind kind 2 de Johan Van der Keuken. Lo importante de la visualización del documental es ayudar a los docentes de educación especial a desprenderse del enfoque socio-constructivista.

Teniendo en cuenta todas las ideas aportadas hasta el momento, podemos afirmar que es un escrito relevante en el campo de la historia de la educación, pues nos ayuda a obtener una compresión idónea de la presencia de la pedagogía y de su impacto en el sistema educativo. Asimismo, nos ayuda a renovar el imaginario colectivo relacionado con la educación, lleno de imágenes relacionadas con la escuela tradicional, y a aprender de las prácticas del pasado.

Estefanía Fernández Antón

Universidad de Barcelona 